$\begin{array}{r}\text { Volume and Issues Obtainable at Center for Sustainability Research and Consultancy } \\ \text { Sustainable Business and Society in Emerging Economies } \\ \text { ISSN: 2708-2504 ISSN (E) 2708-2172 } \\ \text { Volume 1: No. 1, June 2019 } \\ \text { CSRᄃ } \\ \text { Journal homepage: www.publishing.globalcsrc.org/sbsee } \\ \hline\end{array}$

\title{
Credit Risk Oracle: The Bifocal Approach
}

${ }^{1}$ Areeba Khan, ${ }^{2}$ Zulaiha A. Zubair, ${ }^{3}$ Erum Fayyaz, ${ }^{4}$ Iffat Hussain

${ }^{1}$ The Islamia University of Bahawalpur, areeba.khan@iub.edu.pk

${ }^{2}$ Federal University Dutsinma,Katsina State Nigeria, aibrz373@gmail.com

${ }^{3}$ The Islamia University of Bahawalpur, erummf2015@gmail.com

${ }^{4}$ The Islamia University of Bahawalpur, iffat.hussain.550@gmail.com

\begin{tabular}{l}
\multicolumn{1}{c}{ ARTICLE DETAILS } \\
\hline History \\
Revised format: May 2019 \\
Available Online: June 2019 \\
\hline Keywords \\
Credit Risk, Non-Performing \\
Loans, Macro-Economic, Bank \\
Specific, Industrial Sector \\
Growth
\end{tabular}

\section{JEL Classification:}

E51, E59, H81, H89

\begin{abstract}
Financial This study aims to examine the macroeconomic and bank specific predictors of Credit Risk (NPL) and their relevant degree of impact on banks in Pakistan. For bank variables a sample of big 10 banks has been taken from 2009 to 2018. For macro-economic variables sample of 2009 to 2018 has been taken from the world bank. As financial institutions play their role to support industries and alleviate poverty in a country, this study checks the effect of banking variables as well as the economic variables on the credit risk of banks by taking industrial sector growth as a moderator. The study found that NPLs are negatively associated with Lending interest rate, Bank investment, Capital adequacy ratio, Domestic credit to private sector, Financial depth and GDP growth while positively associated with Lending capability, Return on equity, Interest spread and Liquidity Ratio. The moderation effect of Industrial sector growth on the relationship of Lending Capability and NPLs is found to be strengthening the relationship.
\end{abstract}

(C) 2019 The authors, under a Creative Commons Attribution-

NonCommercial 4.0

Corresponding author's email address: areeba.khan@iub.edu.pk

Recommended citation: Khan, A., Zubair, Z. A., Fayyaz, E. \& Hussain, I., (2019). Credit Risk Oracle: The Bifocal Approach. Sustainable Business and Society in Emerging Economies, 1(1), 29-42

DOI: $10.26710 /$ sbsee.v1i1.999

\section{Review of Literature}

During the last decade, the previous studies on credit risk or NPLs has elevated speedily on the variables that could be a reason for financial crisis as an outcome of the treble of NPLs, which is commonly associated with bank failures and economic crises in both developing and developed countries (Mehmood, Hidthiir, \& Nor, 2019). The credit quality of loan portfolios across most countries in the world have been unstable since the global financial crisis (GFC) in 2007- 2008 and therefore the bank asset quality has deteriorated sharply over the years (Kjosevski \& Petkovski, 2016).

There was a significant increase witnessed in the credit growth provided by the financial institutions (Cingolani, 2013). This growth is because of the non-intervention of regulatory body in the financial markets as well as the emergence of information technologies in the banking industry, that has led to the 
cultivation of financial intermediation. Additionally, the deregulation has increased the competition among the banks and financial institutions in European and other markets. Increased credit risk of bank, the literature suggests, is because of the loan portfolios that are advanced by dissatisfactory screening of loans and relaxed borrowing criteria (Jeong \& Jung, 2013). Makri \& Tsagkanos, (2019) have found two major shortcomings in most of the studies. Firstly there is more emphasis given on the macro economic variables as compared to bank related indicators. Secondly, there is no exertion to avoid the constructural changes of Global financial crisis.

NPL is one of the most common indicators through which credit risk can be identified. Non-performing loans (NPL) increased significantly in Pakistan since 2008 when the financial crisis began globally. According to the researchers and the analyst, the forthcoming year will bring the increase in NPLs to the extreme point which will affect the banks' profitability and liquidity, and banking systems' financial stability.

Table 1: Non-Performing Loans of Pakistan as the percentage of GDP

\begin{tabular}{|l|l|l|l|l|l|l|l|l|l|l|l|l|l|l|l|l|}
\hline $\begin{array}{l}\text { Year } \\
\mathrm{s}\end{array}$ & $\begin{array}{l}200 \\
2\end{array}$ & $\begin{array}{l}200 \\
3\end{array}$ & $\begin{array}{l}200 \\
4\end{array}$ & $\begin{array}{l}200 \\
5\end{array}$ & $\begin{array}{l}200 \\
6\end{array}$ & $\begin{array}{l}200 \\
7\end{array}$ & $\begin{array}{l}200 \\
8\end{array}$ & $\begin{array}{l}200 \\
9\end{array}$ & $\begin{array}{l}201 \\
0\end{array}$ & $\begin{array}{l}201 \\
1\end{array}$ & $\begin{array}{l}201 \\
2\end{array}$ & $\begin{array}{l}201 \\
3\end{array}$ & $\begin{array}{l}201 \\
4\end{array}$ & $\begin{array}{l}201 \\
5\end{array}$ & $\begin{array}{l}201 \\
6\end{array}$ & $\begin{array}{l}201 \\
7\end{array}$ \\
\hline $\begin{array}{l}\text { NPL } \\
\text { 's }\end{array}$ & $\begin{array}{l}22 . \\
0\end{array}$ & $\begin{array}{l}17 . \\
0\end{array}$ & $\begin{array}{l}12 . \\
0\end{array}$ & 8.3 & 6.9 & 7.6 & $\begin{array}{l}10 . \\
5\end{array}$ & $\begin{array}{l}12 . \\
6\end{array}$ & $\begin{array}{l}14 . \\
7\end{array}$ & $\begin{array}{l}15 . \\
7\end{array}$ & $\begin{array}{l}14 . \\
6\end{array}$ & $\begin{array}{l}13 . \\
3\end{array}$ & $\begin{array}{l}12 . \\
3\end{array}$ & $\begin{array}{l}11 . \\
4\end{array}$ & $\begin{array}{l}10 . \\
1\end{array}$ & 8.4 \\
\hline
\end{tabular}

Source: Asian Development Bank

\subsection{Problem Statement}

Financial crises are not a new marvel in less developed nations (emerging markets), but they have grown more common, and the financial flows involved have become loftier and more explosive in the past 20 years (Eichengreen et al., 1998). This passé corresponds generally with the era of "economic opening" in emerging markets, a time when most of the Latin American countries, the former Soviet republics, and several Asian countries theatrically reduced their barriers against foreign company undertakings such as imports, foreign direct investment, and foreign portfolio investment(“Global Financial Crises," 2014).

Non-performing loans are also root cause of banking institutions failure(Campbell, 2007). Issue of nonperforming loans is threat to the banking institution's survival(Saba, Azeem \& Kouser, 2012). NPLs indicate financial instability, operational risks as well as inefficient allocations of resources. Thus, determination of factors affecting NLPs is very important. Pakistan's Non-performing Loans Ratio stood at $8.8 \%$ in Sep 2019, compared with the ratio of $8.8 \%$ in the previous quarter.

\subsection{Theoretical Premise for Bank Specific Factors Responsible for Credit Risk}

The following hypotheses are summarized by Klein (2013) through which the relation of bank-specific factors with NPLs can be identified:

- Bad management hypothesis which shows the efficiency of the low cost of the banks which directly indicates the poor management practices, through which the NPL buildup on the control, monitoring, and underwriting of the poor loan.

- Another hypothesis called skimping which shows the efficiency of high cost can enhance the NPLs because the landing risks monitoring is celebrated by pure resources.

- an alternative hypothesis is called the moral hazard hypothesis which contends that NPLs can be pressurized by the moral hazard incentives if the banks are increasing low capital in the loan portfolio to increase the riskiness.

- excess lending contends that that is taking behavior aggressiveness of the bank is attributed by higher NPLs 


\subsection{Lending Capability (LC)}

The economic activities of the banking system can be influenced by the lending method which is the popular method in the banking system. Therefore, bank lending is a very good and useful method for the banking system. One can observe that the economy does not have the power to maintain economic growth level without lending approach (Alejandro \& Guerra, 2017). Some studies show that the lending method may affect the economic growth negatively for different countries (Tahir, Shehzadi, Ali, \& Rizwan Ullah, 2015). However, (Tahir et al., 2015)analyzed that economic growth can be affected by bank lending but for short time intervals. Another researcher (Aurangzeb, 2012) reported that the economic growth of Pakistan has a bi-directional connection. The development of the country depends upon credit. The growth of the banking industry is limited because of the liquidity strains and the industrial sector of the developing countries such as Pakistan may be affected negatively in terms of growth. Another significant factor which affects economic growth is the credit distribution in different private sectors. In Pakistan, the distribution of the credit is done on the basis of the capital-intensive sector and the flow of credit to the priority sector. The bank and other institutions will mobilize the credit from income holders to others. Hence, savings can be converted into loans. These loans can serve the purpose of the financial needs of the investors to do their business (Tahir et al., 2015).

\subsection{Industrial Sector Growth as a Percentage of GDP}

To get a shift from a still/surviving economy to self-sufficient economy, an expeditious industrial development is a main factor of this in developing economies like in Nigeria reports (Keji \& Anderu, 2015). When industrial growth rate increase it will lead to an economy which is less dependent and achieve the objectives of income of per capita, generating more employment and developing local industry by increasing local sources of raw material. It is anticipated that immense industrialization will optimize the utilization of already present resources and cause an increase in the entire economic growth. Industrial sectors has sub sectors like manufacturing, quarrying, mining construction, manufacturing at large and small scale, gas distribution. Mohsen, Chua, \& Sab (2015) conclude their study by stating that agricultural output, population growth and manufactured growth had a positive effect while oil prices had negative effect.

\subsection{Bank Investment}

Investment is crucial constituent of aggregate demand and directing cause of economic growth. Alteration in investment may affect aggregate demand as well as increase the economic growth. The current change in neo-classical model, endogenous growth theory has studied the significance of investment in raising economies (Bint-E-Ajaz \& Ellahi, 2012). The relationship between investment and EG is in bi-causal but Madsen (2002) reports that economic growth greatly depends upon investment.

\subsection{GDP Growth}

The overall economic growth is measured by the gross domestic product (GDP). Economic expansion causes emergence in the income through higher employment, which bring down financial hardship on borrowers. It enables borrowers to assist their debts which will trim down Non-performing Loans for banks(Shingjergji, 2013). Studying literature (Skarica, 2014) reported that during the retardation of economy Non-performing Loan's levels are exaggerated, attributed to increment in unemployment debtors default. Panel data regression study by Salas \& Saurina (2002) reports that credit risk is directly affected by growth in GDP . Nkusu (2011) in his study on the affect of unexpected increase in the Nonperforming Loan ratio on economy of 26 developed countries proves that a $2.4 \%$-point increment in the NPL ratio is connected with a reduction in private borrowing and a $0.6 \%$ point decrease in Gross domestic product growth within the time of first years and the strong counter outcome endure for four years later on the initial shock. 


\subsection{Capital Adequacy Ratio (CAR)}

Sufficient capital reserves with regular maintenance provides necessary financial stability which instill confidence and assurance in customers and creditors. Capital adequacy ratio is used to measure the strength of capital of a bank. It is calculated as regulatory capital expressed as percentage of bank's riskweighted assets. There are three core elements described by prudential guidelines to determine the capital adequacy which are market risk from banking activities, credit risk and the quality of capital held by bank to support exposures from credit risk (Ullah \& Bagh, 2019). Tier I capital consists of common shares, statutory reserves, untaxed reserves (free reserves) and the amount generated from the sales of the asset. This is usually called as essential capital to tackle the risks and losses without compromising on the trade and business in which the bank is involved (Fatima, 2014).

Reserves like hidden reserves, revaluation reserves, hybrid capital, loss reserves and subordinated liabilities comes into the category of Tier II capital. It can be termed as an additional capital which provides cover when the liquidation happens and does not provide enough cover for depositors or customers. Capital Adequacy Ratio can be calculated using the following equation:

\section{$\mathrm{CAR}=$ Tier I + Tier II/Risk Weighted Assets}

\subsection{Profitability Ratio; Return on Equity (ROE)}

Profitability is the measure of the ability of a bank or company to generate profits. Banking performance and macroeconomic stability are related to an important ingredient of financial development which is bank profitability. If macro level is considered, an increase in profitability leads sustainable growth and development. However, regulations need to be in place to avoid higher interest on loans which is possible due to higher returns (Ullah \& Bagh, 2019). The return on investment can be termed as profitability which can be calculated by the net income and the increase in shareholder's total equity for a specific period. Profitability is a very significant measure of any bank's stature as it tells how well the bank is being managed and how beneficial it is for its depositors and shareholders. (Chaibi \& Ftiti, 2015)(Malimi, 2017) through their study have shown that profitability is inversely proportional to NPLs. This means that the bank is not efficiently managed. Abid, Nejib Ouertani, \& Zouari-Ghorbel (2014) agrees with this and further reiterate that there is a statistically significant proof that there is a negative relation between performance and profitability \& NPLs.

\subsection{Liquidity Ratio}

Liquidity of a bank is measured by the ratio of loans to deposit. Liquidity calculates the proportion of funds that the bank use to issue loans from the deposits made by the customers (Makri \& Tsagkanos, 2019). The more the liquidity of a bank is, the more it is entitled in taking big risks. The recent research also depicts a direct relation between liquidity and credit risk.

\subsection{Bank Credit to Private Sector}

Domestic credit by banks to private sector pertains to financial resources provided by depository corporations to the private sector (except central banks). These refer to loans, trade credits and other accounts receivable etc. for which a claim can be filed. Bank credit to private sector (BCPS) includes financing and providing credits by banks or banking institutions to private sector. Bank credit is considered as a valid and significant measure of financial development because traditionally, private sector utilizes the funds much more efficiently than public sector (Ang, 2009). If Pakistani economy is to be considered, it is evident that a lot of defaults have occurred due to unavailability of enough funds from banks for novel projects. The budget deficit is being countered by borrowing from private sector instead of central bank and it has created a pressure on private sector credit. Some studies have reported a positive relationship between bank credit to private sector and credit risk, however, studies like Klein (2013) and Nkusu (2011) have depicted a negative relationship between BCPS and NPLs. 
BCPS as a ratio of GDP depicts the financial strength of a country and as expected it has been found to have a negative impact on NPLs. During the economic uprising, BCPS as indebtness could impact NPLs negatively as shown by Nkusu (2011).

\subsection{Financial Depth}

Out of number of identified indicators (M. W. Klein \& Olivei, 2008) from the previous empirical literature they focused on indicators of financial intermediary development. The selected proxy of financial depth was liquid liabilities indicator LLY which shows the ratio of liquid liabilities to Gross domestic product, which shows the complete size financial intermediary sector without excluding the credit provided to the governmental and quasi-governmental agencies. So, they also employed an indicator named PRIVY which is a ratio of the credit provided by financial intermediaries to Private sector to the gross domestic product.

\subsection{Interest Spread}

The interest is actually an amount paid by the borrower for the use of money borrowed by him over a period of time, or it can be supposed as a rent for the money to be used by the borrower Crowley (2007) It is affirmed in the case of Kenya banks that an increase in interest rate spread causes increase in the interest charged from the borrowers which causes a low in performance of assets. A recent sudy (Farhan, Sattar, Hussain, \& Fareeha, 2012) found that bank advances loans at a higher interest rate to those clients who are unable to pay back the loan or it is harder for them to pay back. Further exploring the reasons, they found interest rates to be one of the reasons responsible that cause NPLs. So, moving towards the relationships we first learn about the deposit interest rate, lending interest rate, real interest rate. Also, to calculate the real interest rate GDP deflator is employed so we shall see the description of GDP deflator.

\subsection{Real Interest Rate}

World Bank defines real interest rate as the lending interest rate which is adjusted for inflation as measured by GDP inflator over a year. For the calculation of the real interest rate the conditions and terms are distinct country wise because of which this cannot be used to compare the countries data("Real interest rate (\%) - Pakistan | Data," n.d.).

\subsection{GDP Deflator}

The ratio of gross domestic product in current local currency to the constant local currency to the constant local currency is said to be the GDP deflator. The constant local currency is taken constant of any base year and it is calculated annually. Basically, GDP deflator serves in the calculation of real interest rate. However, for each country the base year of constant value is different, despite being a macro-economic variable this shortcoming of real interest rate limits the comparability of the real interest rate of different countries.

\subsection{Lending Interest Rate}

The rate over which the banks provide debt to fulfill the short term and long -term financing needs of the private sector (over a year). While advancing the loan banks keep in view the goal to take the loan and credibility of the borrower this rate is varied defined by. Also, the terms and conditions to issue these loans vary which limits the comparability of this ratio among different countries("Lending interest rate (\%) - Pakistan | Data," n.d.)

\subsection{Deposits Interest Rate}

As a return to the deposits tools that are demand deposits, time deposits and savings deposits. The rate paid by the commercial banks is the deposits interest rate. This rate is affected by the different conditions that are country specific. So, this fact also hinders the comparison of this rate. 


\subsection{Objectives}

The main objective of research is to evaluate the effect of the factors affecting credit risk in banks of Pakistan.

- To check effect of bank investment on credit risk.

- To evaluate impact of some bank related variables like BI, CAR, Liquidity ratio, profitability ratio, interest spread on credit risk.

- To identify effect of macroeconomic variables including bank credit to private sector, GDP, Lending interest rate and financial depth on credit risk of banks in Pakistan.

- To identify the significance of Industrial Sector Growth as moderator between lending capability and credit risk.

- This study aims to examine the predictors of Credit Risk (NPL) and their relevant degree of impact on credit risk of banks in Pakistan.

\section{Data and Methodology}

Table 2

\begin{tabular}{|c|c|c|c|c|}
\hline Determinants & Type & Symbol & Proxy/measure & Source \\
\hline Credit risk & DV & NPL & $\begin{array}{l}\text { Non-Performing Loans /Total } \\
\text { Loans }\end{array}$ & World Development Indicators \\
\hline $\begin{array}{l}\text { Industrial Sector } \\
\text { (Salas \& Saurina, 2002) }\end{array}$ & IV & Industry & Industry as a Percentage of GDP & World Development Indicators \\
\hline Industrial Sector Growth & Moderator & ISG & $\begin{array}{l}\text { Manufacturing, value added (\% } \\
\text { of GDP), Industry (including } \\
\text { construction), value added ( } \% \text { of } \\
\text { GDP) }\end{array}$ & World Development Indicators \\
\hline $\begin{array}{l}\text { Lending Capability } \\
\text { (Saeed, Ramzan, \& Hamid, } \\
\text { 2018) }\end{array}$ & Bank related & LC & Loan to deposit ratio & Banks' annual financial reports \\
\hline $\begin{array}{l}\text { Bank investment } \\
\text { (Saeed, Ramzan, \& Hamid, } \\
\text { 2018) }\end{array}$ & Bank related & $\mathrm{BI}$ & Investment to total asset ratio & $\begin{array}{l}\text { Banks' annual financial repor } \\
\text { Ts }\end{array}$ \\
\hline $\begin{array}{l}\text { Capital adequacy Ratio(Irum } \\
\text { Saba, Sakina Narmeen, } \\
\text { Rehana Kouser \& Harris } \\
\text { Khurram, 2012) }\end{array}$ & Bank related & CAR & $\begin{array}{l}\text { Tier I + Tier II / Risk Weighted } \\
\text { Assets (RWA) }\end{array}$ & Banks' annual financial reports \\
\hline $\begin{array}{l}\text { Profitability Ratio } \\
\text { ROE(Waqas, Fatima, Khan, \& } \\
\text { Arif, 2017) }\end{array}$ & Bank related & ROE & Net Income/Shareholders equity & Banks' annual financial report \\
\hline $\begin{array}{l}\text { Liquidity Ratio(Kumar \& } \\
\text { Kishore, 2019) }\end{array}$ & Bank related & LR & Total Loans/ Total Assets & Banks' annual financial report \\
\hline $\begin{array}{l}\text { Interest rate Spread } \\
\text { Farhan, Sattar, Hussain, \& } \\
\text { Fareeha, 2012) }\end{array}$ & Bank related & IS & Lending rate minus deposit rate & World Development Indicators \\
\hline $\begin{array}{l}\text { Bank credit to private } \\
\text { sector(Mehmood et al., 2019) }\end{array}$ & Macro-Economic & BCPS & $\begin{array}{l}\text { Domestic credit to private sector } \\
\text { by banks ( } \% \text { of GDP) }\end{array}$ & World Development Indicators \\
\hline $\begin{array}{l}\text { GDP } \\
\text { (Mehmood et al., 2019) }\end{array}$ & Macro-Economic & GDP & GDP growth (annual \%) & World Development Indicators \\
\hline $\begin{array}{l}\text { Lending Interest Rate } \\
\text { (Mehmood et al., 2019) }\end{array}$ & Macro-Economic & LIR & Lending interest rate $(\%)$ & World Development Indicators \\
\hline $\begin{array}{l}\text { Financial Depth } \\
\text { (M. W. Klein \& Olivei, 2008) }\end{array}$ & Macro-Economic & FD & $\begin{array}{l}\text { Depth of credit information } \\
\text { index }(0=\text { low to } 8=\text { high })\end{array}$ & World Development Indicators \\
\hline
\end{tabular}


The table is said to be the extract of literature reviewed. All the banking and macro-economic variables and proxy measures are given in the table and their sources from where the data will be obtained.

\section{Table 3}

\begin{tabular}{|l|l|l|l|}
\hline Sr. No. & Bank Name & Sr. No. & Bank Name \\
\hline 1 & National Bank of Pakistan (NBP) & 6 & Meezan Bank \\
\hline 2 & Bank Alfalah & 7 & Allied Bank (ABL) \\
\hline 3 & Standard Chartered Bank & 8 & Askari Bank \\
\hline 4 & Habib Bank Limited (HBL) & 9 & MCB \\
\hline 5 & United Bank Limited (UBL) & 10 & Bank al Habib \\
\hline
\end{tabular}

Source: Corporate Finance Institute (CFI)

\section{Research Framework}

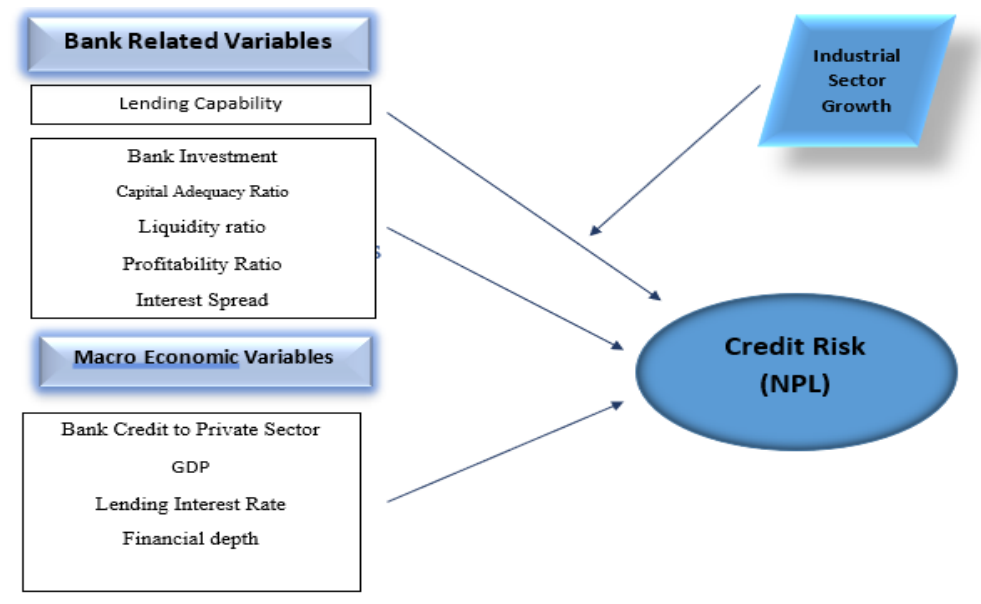

Figure 2 Research Fraework

The data obtained from Pakistani banks for bank variables and world bank indicators shows the following trends and relationships with credit risk.

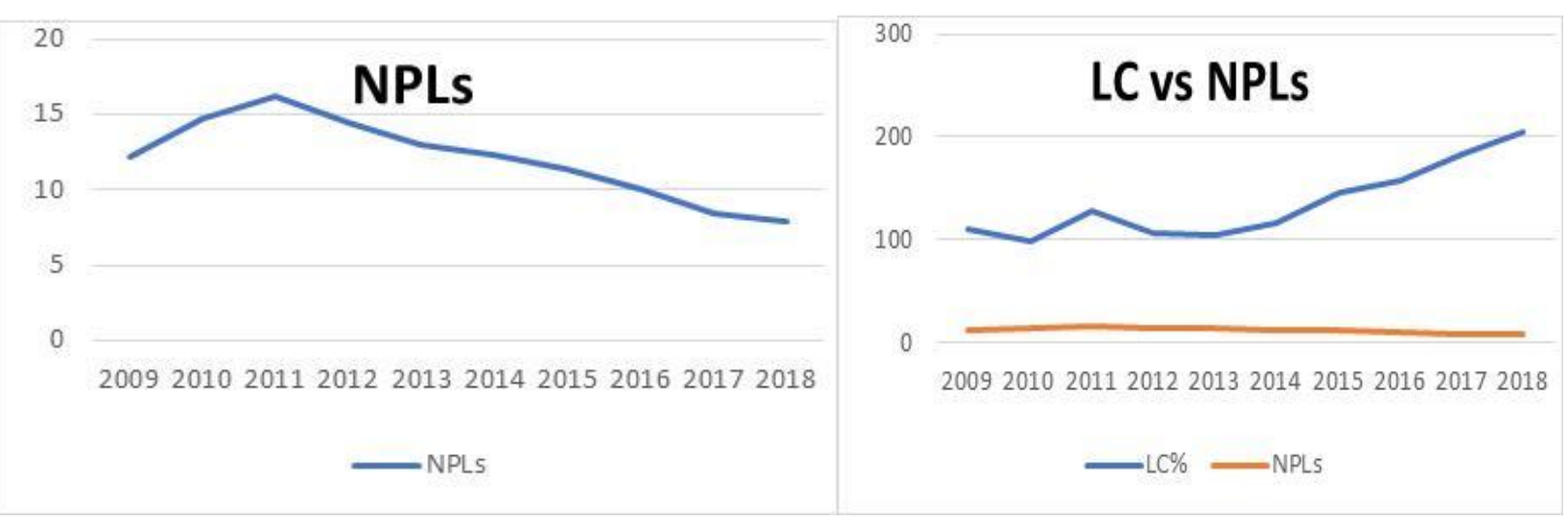




\section{LC and Industry vs NPLs}

150

100

50

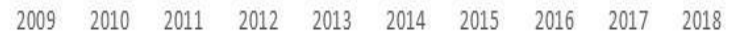

$-\mathrm{LC} \%=$ NPLS Industry

\section{CAR vs NPLs}

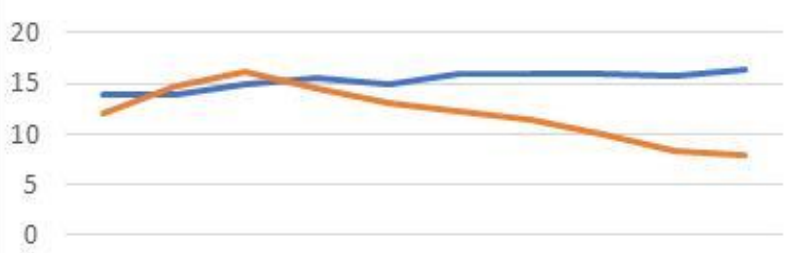

2009201020112012201320142015201620172018
Industry, Industrial sector growth vs NPLs

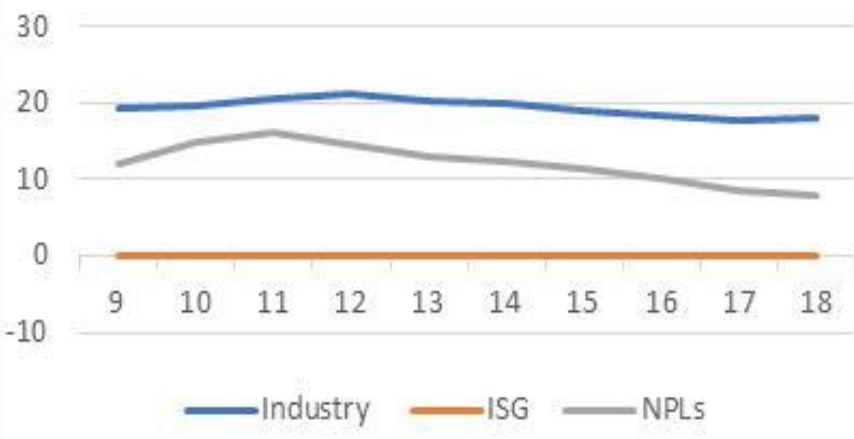

\section{GDP Growth vs NPLs}

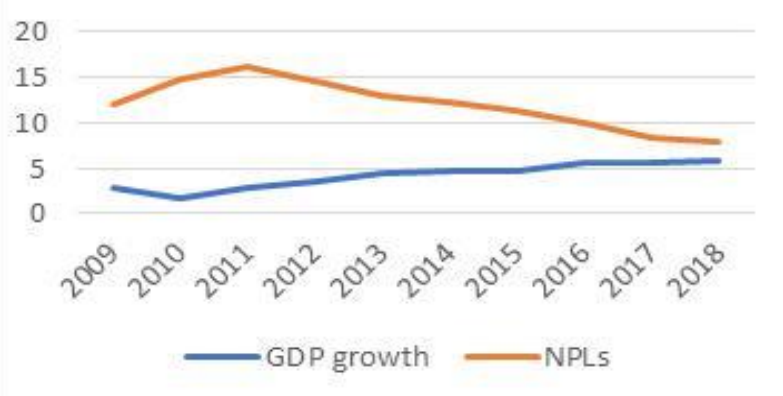

\section{LR vS NPLS}
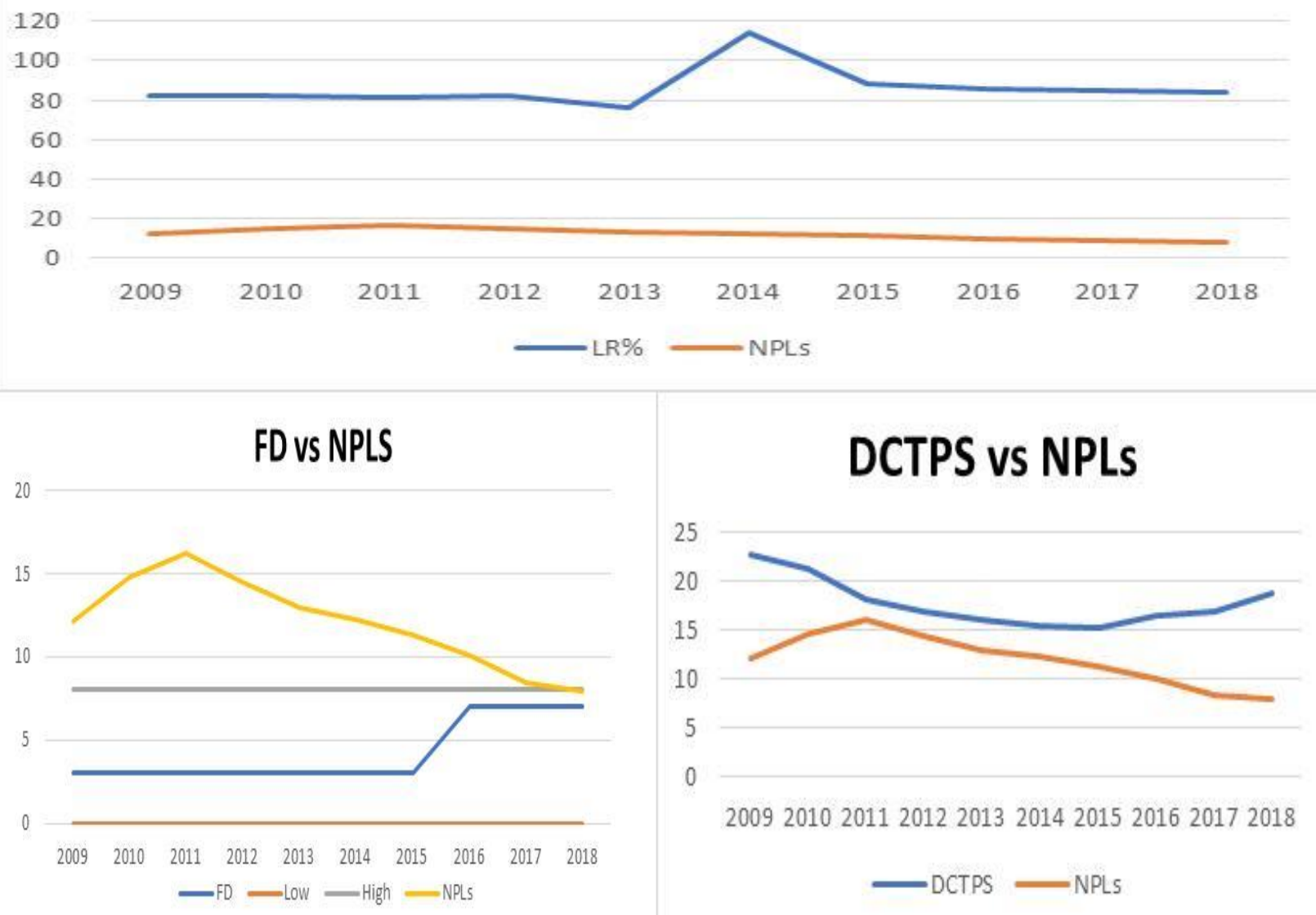

\section{DCTPS vs NPLS}

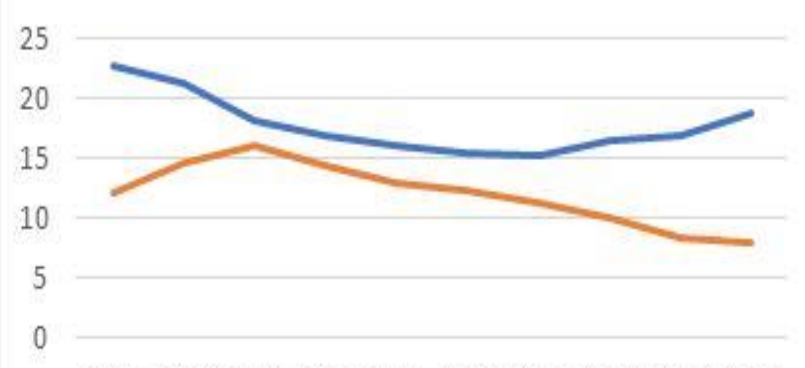

2009201020112012201320142015201620172018

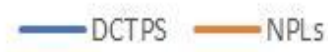




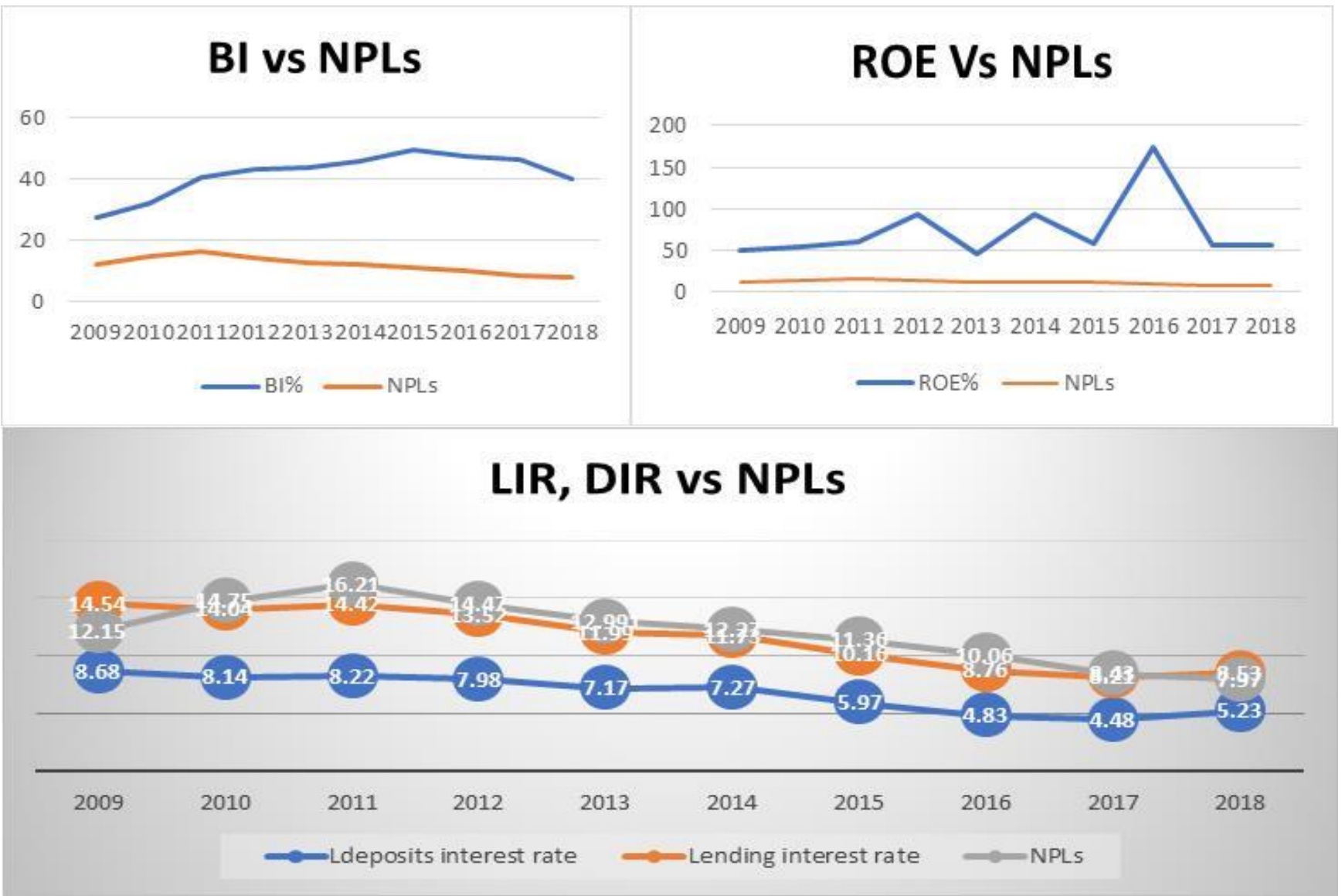

So, we can assert that as the more accurate and transparent information is available to the financial intermediaries, they use it at optimum level and make the non-performing loans to reduced Estimating Equation 1

Table 4

\begin{tabular}{|crcrr|}
\hline Variable & Coefficient & Std. Error & t-Statistic & \multicolumn{1}{c|}{ Prob. } \\
\hline \hline C & 118.17 & 28.96 & 4.08 & 0.05 \\
BI & -0.74 & 0.20 & -3.55 & 0.07 \\
DCTPS & -1.33 & 0.97 & -1.37 & 0.30 \\
FD & -2.94 & 0.69 & -4.21 & 0.05 \\
GDPGRWTH & -0.17 & 0.33 & -0.49 & 0.66 \\
LC & -2.92 & 0.39 & -7.29 & 0.01 \\
ROE & 0.06 & 0.02 & 2.32 & 0.14 \\
R-squared & 0.022 & 0.01 & 2.27 & 0.15 \\
Adjusted R-squared & 0.99 & Mean dependent var & 12.06 \\
S.E. of regression & 0.96 & S.D. dependent var & 2.69 \\
Sum squared resid & 0.51 & Akaike info criterion & 1.47 \\
Log likelihood & 0.52 & Schwarz criterion & 1.72 \\
F-statistic & 0.60 & Hannan-Quinn criter. & 1.21 \\
Prob(F-statistic) & 35.82 & Durbin-Watson stat & $2.06 \mid$ \\
\hline \hline
\end{tabular}

Table 5 depicts the summary of the regression results which are obtained by applying ordinary least square method. Data ranges from 2008 to 2019. The adjusted R-squared value is $96 \%$..it means that all above mentioned variables cumulatively express NPLs by $96 \%$. It means that independent variables contribute to NPLs by $96 \%$. The probability values shows the significance of all independent variables in this data with the dependent variable. 
In this table domestic credit to private sector and GDP growth are significant with NPLs whereas other variables like BI, CAR, FD, LC and ROE have insignificant relation with NPLs. Probability value less than 0.05 shows that respected independent variables explain the dependent variable in a good way.

Lastly Durban-Watson test show the autocorrelation between the varibales of the dataset. For a good regression model Durban Watson has to be value of 2.if its value is less than 2 it means positive autocorrelation of the dataset. Value above 2 show negative autocorrelation.

\section{Estimating Equation 2}

\section{Table 5}

\begin{tabular}{|crrrr|}
\hline Variable & Coefficient & Std. Error & t-Statistic & Prob. \\
\hline \hline C & -2.85 & 5.19 & -0.55 & 0.60 \\
INTSP & 2.72 & 2.12 & 1.28 & 0.25 \\
LIR & -0.09 & 0.84 & -0.11 & 0.91 \\
LR & 0.04 & 0.04 & 0.71 & 0.50 \\
\hline \hline R-squared & 0.85 & Mean dependent var & 12.06 \\
Adjusted R-squared & 0.77 & S.D. dependent var & 2.69 \\
S.E. of regression & 1.29 & Akaike info criterion & 3.64 \\
Sum Squared resid & 10.00 & Schwarz criterion & 3.76 \\
Log likelihood & -14.19 & Hannan-Quinn criter. & 3.50 \\
F-statistic & 11.11 & Durbin-Watson stat & 1.041 \\
Prob(F-statistic) & 0.007 & & & \\
\hline
\end{tabular}

In this table it has negative autocorrelation dataset.

In this table of dataset no variable is significant and adjusted R-squared value is $77 \%$.Durban Watson shows value of 1.04 which means that there is positive autocorrelation of the dataset.

\section{Estimating Equation 3}

\section{Table 6}

\begin{tabular}{|crcrr|}
\hline \hline Variable & Coefficient & Std. Error & t-Statistic & \multicolumn{1}{c|}{ Prob. } \\
\hline \hline C & -19.24 & 8.15 & -2.36 & 0.065 \\
INTSP & 2.78 & 1.17 & 2.38 & 0.06 \\
LIR & -0.63 & 0.55 & -1.16 & 0.29 \\
MODEEFFECT & $-7.55 \mathrm{E}-05$ & 0.01 & -0.09 & 0.94 \\
INDUSTRY & 1.32 & 0.39 & 3.32 & 0.02 \\
\hline \hline R-squared & 0.95 & Mean dependent var & 12.06 \\
Adjusted R-squared & 0.91 & S.D. dependent var & 2.69 \\
S.E. of regression & 0.80 & Akaike info criterion & 2.71 \\
Sum squared resid & 3.22 & Schwarz criterion & 2.86 \\
Log likelihood & -8.53 & Hannan-Quinn criter. & 2.54 \\
F-statistic & 24.17 & Durbin-Watson stat & 2.19 \\
Prob(F-statistic) & 0.02 & & \\
\hline
\end{tabular}

In this table moderator effect is shown. Industry has probability value of 0.02 which is less than 0.05 . It means that industry has significant relation with NPLs. Moreover, adjusted R-square value increases from $77 \%$ to $91 \%$ which shows that moderator has created significant increase in the model. We may say that by introducing moderation non-performing loans increases as industrial effect increase. 


\section{Conclusion}

Credit risk is the risk of failing to fulfill an obligation on any liability by borrower. In any economy, as financial sector considered is the backbone of any economy. That's why it has strong interaction with the survival of any economy. As Pakistan is a developing country so in our economy banks act like financial intermediaries and cycle deposits into lend-lease. In different portfolios of banks loans are main earning asset of banks which it earns by giving different lending. In order to earn profits, if banks give more loans then there are also chances or threat of risk increases. So, proper allocation of loans is necessary.

Macroeconomic factors are like some events of a bigger scale of the geographical, political, seasonal, natural or any other types that may affect economy of any country through affecting the businesses in a monetary measure. These factors are not only monitored by government authorities but also by private agencies to interpret the occurred events, check the causality of events as well as predict any forthcoming event.

NPLs are also the main cause of bank failures(Campbell, 2007). In fact, NPLs issue is critical to the survival of banking institutions(Saba, Azeem Kouser, 2012). Also, it is one of the financial stability indicators and it shows both credit and operational risks as well as represent efficient allocation of resources. Therefore, determining the factors that influence NPLs is of prime importance. It is also taken as proxy of credit risk.

An increase in NPLs demand higher provisions for bad loans and they cause the fall in the efficiency indicators of banks that are basically liquidity ratio and profitability ratios which hoovers the income efficiency of banks. The liquidity problem arises due to the mismatch of the maturities in assets and liabilities following the matching principal and corrosion in the credit rating also a decay in bank image in a long run(Badar \& Yasmin Javid, 2013). The matching of assets and liabilities is a technique to measure the risk faced by banks and over which the banks' credit rating is based(Thakker \& Chakraborty, 2018).

After getting results by employing data it is concluded that

- GDP and DCTPS are statistically significant. So, they are affecting the non-performing loans.

- Coefficient of GDP is negative which means that when GDP increases NPLs reduces. It means borrowers are capable to repay their loans.

- Domestic credit to private sector also shows significant and negative relation to NPLs which means that when credit to private sector increases NPLs reduces.

- Industry has significant and positive relation with non-performing loans. Which means when industrial sector grows non-performing loans will increase.

- Lending capability shows positive relation with NPLs that means as lending capability increases NPLs also increase. But statistically it has proved insignificant.

- With the introduction of moderator which is industrial sector growth and it has taken by multiplying industry with lending capability the value of adjusted $\mathrm{R}$ square increases which shows that moderator has strengthening impact on the relationship of dependent variable which is non-performing loans and independent variable which is lending capability.

- Bank Investment, CAR, Lending Interest rate, liquidity ratio, ROE, Interest spread and Financial Depth were found to be insignificant with non-performing loans.

\section{Recommendations From Research are as Follows}

- Firstly, the banks should focus on the ratio of industry as the percentage of GDP and make the forecast of the growth in industrial sector and the demand of loans from the industrial sector. Because there is a positive and strong relation between credit risk and industrial growth. So, if there is a growth in industry be forecasted then ultimately be rise in demand for loans. 
- As there is positive relation between lending capability and credit risk. So, there is a need to make such policies that should prevent the growth in NPLs. It can be asserted that when the demand for loans from industrial rises then banks will have to make more lending as it is a supply side.

- As moderator strengthens the relationship between lending capability and NPLs so the banks should project growth in the industrial sector in order to control the ratio of NPLs.

- State Bank of Pakistan may use the resulting information to formulate policies that may support banks in minimizing the NPLs.

- State bank and bankers should take comments or suggestions from industrialists. Investment division should do this on priority basis and after taking recommendations from them they should implement the required policies on broader spectrum. Government should make policies which tighten the lending process so that NPLs can be reduced.

\section{References}

Abid, L., Nejib Ouertani, M., \& Zouari-Ghorbel, S. (2014). Macroeconomic and Bank-specific Determinants of Household's Non-performing Loans in Tunisia: A Dynamic Panel Data. Procedia Economics and Finance, 13, 58-68. https://doi.org/10.1016/S2212-5671(14)00430-4

Abid Mehmood), Hidthiir, Dr. Mohmad Helmi Bin, \& Nor, Dr. Alias Mat, U. U. M. (UUM)). (2019). A Conceptual Paper for Macroeconomic Determinants of Non-Performing Loans (NPLs) in Banking Sector of Pakistan. Asian Journal of Multidisciplinary Studies, 7(3), 6-15.

Alejandro, E., \& Guerra, R. (2017). The economic growth and the banking credit in Mexico :

Ang, J. B. (2009). Financial development and the FDI-growth nexus: The Malaysian experience. Applied Economics, 41(13), 1595-1601. https://doi.org/10.1080/00036840701222553

Aurangzeb. (2012). CONTRIBUTIONS OF BANKING SECTOR IN ECONOMIC GROWTH : A Case of Pakistan. Economics and Finance Review, 2(6), 45-54. Retrieved from http://www.businessjournalz.org/efr

Badar, M., \& Yasmin Javid, A. (2013). Impact of macroeconomic forces on nonperforming loans: An empirical study of commercial banks in Pakistan. WSEAS Transactions on Business and Economics, 10(1), 40-48.

Bint-E-Ajaz, M., \& Ellahi, N. (2012). Public-private investment and economic growth in Pakistan: An empirical analysis. Pakistan Development Review, 4(51), 61-77.

Campbell, A. (2007). Bank insolvency and the problem of nonperforming loans. Journal of Banking Regulation, 9(1), 25-45. https://doi.org/10.1057/palgrave.jbr.2350057

CFI. (2019). Top Banks in Pakistan - Overview, Guide to Top 10 Banks in Pakistan. Retrieved February 21, 2020, from https://corporatefinanceinstitute.com/resources/careers/companies/top-banks-inpakistan/

Chaibi, H., \& Ftiti, Z. (2015). Credit risk determinants: Evidence from a cross-country study. Research in International Business and Finance, 33, 1-16. https://doi.org/10.1016/j.ribaf.2014.06.001

Cingolani, M. (2013). Finance capitalism: A look at the European financial accounts. Panoeconomicus, 60(2 SPEC. ISSUE), 249-290. https://doi.org/10.2298/PAN1303249C

Crowley, J. (2007). Interest Rate Spreads in English-Speaking African Countries. Retrieved February 15, 2020, from https://www.imf.org/en/Publications/WP/Issues/2016/12/31/Interest-Rate-Spreads-inEnglish-Speaking-African-Countries-20629

Deposit interest rate (\%) - Pakistan | Data. (n.d.). Retrieved February 17, 2020, from https://data.worldbank.org/indicator/FR.INR.DPST?locations=PK

Depth of credit information index (0=low to 8=high) - Pakistan $\mid$ Data. (n.d.). Retrieved February 16, 2020, from https://data.worldbank.org/indicator/IC.CRD.INFO.XQ?locations=PK

Farhan, M., Sattar, A., Hussain, A., \& Fareeha, C. (2012). Economic Determinants of Non-Performing Loans : Perception of Pakistani Bankers, 4(19), 87-100.

Fatima, N. (2014). Capital Adequacy: A Financial Soundness Indicator for Banks. Global Journal of Finance and Management, 6(8), 975-6477. Retrieved from http://www.ripublication.com 
Global Financial Crises. (2014).

Jeong, S., \& Jung, H. (2013). Bank wholesale funding and credit procyclicality: Evidence from Korea. Panoeconomicus, 60(5), 615-631. https://doi.org/10.2298/PAN1305615J

Keji, O. J. A., \& Anderu, S. (2015). An Assessment of the Determinants of Industrial Sector Growth in Nigeria. Quest Journals Journal of Research in Business and Management, 3(7), 1-9. Retrieved from www.questjournals.org

Kjosevski, J., \& Petkovski, M. (2016). Baltic States: determinants and macroeconomic effects. Baltic Journal of Economics, 17(1), 25-44. https://doi.org/10.1080/1406099X.2016.1246234

Klein, M. W., \& Olivei, G. P. (2008). Capital account liberalization, financial depth, and economic growth. Journal of International Money and Finance, 27(6), 861-875. https://doi.org/10.1016/j.jimonfin.2008.05.002

Klein, N. (2013). Non-Performing Loans in CESEE: Determinants and Impact on Macroeconomic Performance. IMF Working Papers, 13(72), 1. https://doi.org/10.5089/9781484318522.001

Kumar, V., \& Kishore, M. P. (2019). Macroeconomic and Bank Specific Determinants of NonPerforming Loans in UAE Conventional Bank, 2(1), 1-12.

Lending interest rate (\%) - Pakistan | Data. (n.d.). Retrieved February 17, 2020, from https://data.worldbank.org/indicator/FR.INR.LEND?locations=PK

Madsen, J. B. (2002). The causality between investment and economic growth. Economics Letters, 74(2), 157-163. https://doi.org/10.1016/S0165-1765(01)00549-3

Makri, Tsagkanos, and B. 2014). (2019). Nonperforming Loans in Asia: Determinants and Macrofinancial Linkages. SSRN Electronic Journal, (574).

Malimi, K. (2017). The Influence of Capital Adequacy, Profitability, and Loan Growth on NonPerforming Loans a Case of Tanzanian Banking Sector. International Journal of Economics, Business and Management Studies, 4(1), 38-49. https://doi.org/10.20448/802.41.38.49

Mehmood, A., Hidthiir, M. H. Bin, \& Nor, A. M. (2019). The impact of external factors on stressed banking assets: An evidence from Pakistani conventional banks. Journal of Economics and Sustainability, 1(2), 11-21. Retrieved from http://www.jes.uum.edu.my/images/current/vollissue22019/Paper_2_abstract_2019_02_JES_Vo lume_1_Issue_26_July_2019.pdf

Mohsen, A. S., Chua, S. Y., \& Sab, C. N. C. (2015). Determinants of industrial output in Syria. Journal of Economic Structures, 4(1). https://doi.org/10.1186/s40008-015-0030-7

Nkusu, M. (2011). Nonperforming Loans and Macrofinancial Vulnerabilities in Advanced Economies; by Mwanza Nkusu; IMF Working Paper 11/161; July 1, 2011. Retrieved from https://www.imf.org/external/pubs/ft/wp/2011/wp11161.pdf

Pakistan GDP distribution 2018 Statista. (n.d.). Retrieved February 18, 2020, from https://www.statista.com/statistics/383256/pakistan-gdp-distribution-across-economic-sectors/

Real interest rate (\%) - Pakistan | Data. (n.d.). Retrieved February 15, 2020, from https://data.worldbank.org/indicator/FR.INR.RINR?locations=PK

Saba, Irum, Rehana Kouser, M. A. (2012). Determinants of Non Performing Loans: Case of US Banking Sector. Romanian Economic Journal, (June 2012), 141-152.

Saeed, M. Y., Ramzan, M., \& Hamid, K. (2018). Dynamics of Banking Performance Indicators and Economic Growth : long-Run Financial Development Nexus in Pakistan, 7(3), 141-163.

Salas, V., \& Saurina, J. (2002). Credit risk in two institutional regimes: Spanish commercial and savings banks. Journal of Financial Services Research, 22(3), 203-224. https://doi.org/10.1023/A:1019781109676

Shingjergji, A. (2013). The Impact of Macroeconomic Variables on the Non Performing Loans in the Albanian Banking System During 2005 - 2012. Academic Journal of Interdisciplinary Studies, 2(9), 335-339. https://doi.org/10.5901/ajis.2013.v2n9p335

Skarica, B. (2014). Determinants of non-performing loans in Central and Eastern European countries. Financial Theory and Practice, 38(1), 37-59. https://doi.org/10.3326/fintp.38.1.2

Tahir, S. H., Shehzadi, I., Ali, I., \& Rizwan Ullah, M. (2015). Impact of Bank Lending on Economics Growth in Pakistan: An Empirical Study of Lending to Private Sector. American Journal of 
Industrial and Business $\quad$ Management, 565-576. https://doi.org/10.4236/ajibm.2015.58056

Thakker, K., \& Chakraborty, T. (2018). Asset Liability Management in Commercial Banks in India. In Advances in Finance \& Applied Economics (pp. 299-316). Springer Singapore. https://doi.org/10.1007/978-981-13-1696-8_18

The Basics of the Industrials Sector. (n.d.). Retrieved February 18, 2020, from https://www.fool.com/investing/general/2012/09/19/the-basics-of-the-industrials-sector.aspx

Ullah, K., \& Bagh, T. (2019). Finance and Management Scholar at Riphah International University Islamabad, Pakistan, Faculty of Management Sciences, 10(10), 84-91. https://doi.org/10.7176/RJFA

Waqas, M., Fatima, N., Khan, A., \& Arif, M. (2017). Determinants of Non-performing Comparative Study of Pakistan, Loans : A. Journal of Finance \& Banking Studies, 6(1), 51-68. 